\title{
Mechanism for the development of ovarian cysts in patients with congenital lipoid adrenal hyperplasia
}

\author{
M Shima, A Tanae ${ }^{1}$, K Miki, N Katsumata ${ }^{2}$, S Matsumoto, S Nakajima, T Harada, T Shinagawa ${ }^{2}$, T Tanaka ${ }^{2}$ \\ and S Okada \\ Department of Pediatrics, Osaka University, Faculty of Medicine, Yamadaoka, Suita City, Osaka 565-0871, Japan, ${ }^{1}$ Division of Endocrinology and \\ Metabolism, National Children's Hospital, Japan and ${ }^{2}$ Department of Endocrinology and Metabolism, National Children's Medical Research Center, \\ 3-35-31, Taishido, Setagaya-ku, Tokyo 154-8509, Japan \\ (Correspondence should be addressed to M Shima; Email: masa@ped.med.osaka-u.ac.jp)
}

\begin{abstract}
Objective: Although ovarian cysts commonly occur in patients with congenital lipoid adrenal hyperplasia (CLAH), the mechanism of development remains to be determined. To clarify the pathogenesis of the ovarian cysts, endocrinological examinations were performed in patients with CLAH.

Methods: The subjects were three Japanese CLAH patients. Basal body temperature, serum and urinary gonadotropin levels, serum and/or urinary ovarian hormones and mutations of the steroidogenic acute regulatory protein (StAR) gene were examined.

Results: The basal body temperature was not biphasic in any patient. Basal LH levels were high in all CLAH patients and markedly responded to LH-releasing hormone in two patients. Urinary gonadotropin analysis revealed repetitive LH surges in the menstrual cycles of the CLAH patients. No increase in the urinary pregnanediol suggested anovulation in all patients, and bilateral ovarian cysts were found in two of the subjects. Examination of the StAR gene revealed a frameshift mutation 840delA at codon 238, a nonsense mutation Q258X at codon 258, a homozygotic mutation at Q258X, and a compound heterozygotic mutation with 251insG and Q258X.

Conclusions: We concluded that the development of ovarian cysts may be derived from continued anovulation in CLAH patients. Elevated LH levels may be explained by increased sensitivity of the anterior pituitary to circulating estrogen.
\end{abstract}

European Journal of Endocrinology 142 274-279

\section{Introduction}

Congenital lipoid adrenal hyperplasia (CLAH) is an autosomal recessive disorder caused by defective pregnenolone production, an initial step in steroid biosynthesis, in the gonads and adrenal glands (1). This disorder is characterized by hyponatremia, hyperkalemia, hypoglycemia and pigmentation, and is fatal without treatment. Absence of androgen is another important character in CLAH, and thus 21 hydroxylase or $11 \beta$ hydroxylase deficiency can be differentiated from CLAH by a high androgen level, and $3 \beta$ hydroxylase deficiency by a low level of androgen and high dehydroepiandrosterone and 17-OH pregnenolone. A cholesterol sidechain cleavage enzyme, P450scc, which converts cholesterol to pregnenolone has been examined but no abnormality of the enzyme has been found (2). Recently, Clark and colleagues $(3,4)$ clarified that steroidogenic acute regulatory protein (StAR) is a carrier protein that transfers cholesterol from the outer to inner membrane of mitochondria, where P450scc is located. They also demonstrated that a defect of biosynthesis of this protein causes CLAH (4).

Karyotype 46,XY individuals with CLAH fail to develop male external genitalia and to undergo spontaneous puberty. However, in XX patients with CLAH, spontaneous puberty has been reported to develop without treatment (5). Bose et al. (6) have hypothesized that the fetal ovary is saved from damage by accumulating lipid droplets because it remains unstimulated until puberty, while the fetal testis, which is stimulated by chorionic gonadotropin in early gestation, is severely affected early in gestation and fails to develop male external genitalia. The onset of puberty in female CLAH patients stimulates the individual ovarian follicles and produces some steroidogenesis by a StAR-independent pathway. The previously unstimulated follicles are recruited in subsequent 
cycles, permitting a low level of steroidogenesis. This hypothesis explains the difference between the fetal ovary and testis and the mechanism for the spontaneous puberty observed in female CLAH patients. However, the pathogenesis of ovarian cysts observed frequently in CLAH patients remains to be determined (7). We present three CLAH patients, two of whom were complicated by ovarian cysts. To clarify the mechanism for the development of the ovarian cysts, endocrinological functions in these patients were examined.

\section{Case reports}

\section{Case 1}

A 4-month-old Japanese female infant was referred to Osaka University Hospital for treatment of electrolyte abnormalities. She was delivered vaginally after 40 gestational weeks and her birth weight was $3550 \mathrm{~g}$. An adrenal insufficiency was suspected due to prolonged hyponatremia, hyperkalemia, hypoglycemia and generalized pigmentation at 20 days after birth. No increase in either the serum cortisol or aldosterone levels was observed after the adrenocorticotropin (ACTH) injection. A physical examination revealed a malnourished infant with generalized pigmentation. Her external genitalia were normal, and her karyotype was 46,XX. Body weight was $3150 \mathrm{~g}(-4.3$ S.D. $)$ and height $57 \mathrm{~cm}$ $(-2.5$ S.D.). Abnormal laboratory findings were as follows: serum sodium $124 \mathrm{mEq} / \mathrm{l}$, serum potassium $5.4 \mathrm{mEq} / \mathrm{l}, \mathrm{ACTH}>850 \mathrm{pg} / \mathrm{ml}$ and plasma renin activity $>80 \mathrm{ng} / \mathrm{ml}$ per h. By combined treatment with hydrocortisone and $9 \alpha$-fluorocortisone acetate, the serum sodium and potassium levels recovered and maintained normal levels. Breast budding and menarche occurred at the ages of 9 and 10 respectively. However, her menstrual cycle has been irregular. At the age of 11 , she was diagnosed as having right ovarian cysts (right ovary in whole size: $41 \times 38 \mathrm{~mm}$ ) by ultrasonography when she visited another hospital due to abdominal pain. At the age of 13, breast development was at Tanner stage 5 and pubic hair distribution at Tanner stage 2, but axillary hair was not found. Ultrasonography in our hospital revealed bilateral ovarian cysts (right ovary in whole size, $46 \times 34 \times 28 \mathrm{~mm}$; left ovary, $71 \times 47 \times 48 \mathrm{~mm})$. Magnetic resonance imaging revealed ovarian cysts with diameters of more than $20 \mathrm{~mm}$ in both ovaries. Ultrasonography examined at 6-month intervals showed bilateral ovarian cysts on every occasion. Replacement therapy with estrogen and progesterone was started at the age of 14 , relieving the abdominal pain and diminishing the ovarian cysts. After the 10-month treatment, both ovaries were decreased in size (right ovary in whole size, $30 \times 20 \times 20 \mathrm{~mm}$; left ovary, $27 \times 27 \times 21 \mathrm{~mm})$. The StAR gene analysis revealed a compound heterozygote having a heterozygous frameshift mutation 840delA at codon 238 and heterozygous nonsense mutation Q258X at codon 258 .

\section{Case 2}

A 3-day-old Japanese girl developed hyponatremia, hyperkalemia, pigmentation, hypothermia and convulsions and was diagnosed as having congenital adrenal insufficiency. Urinary 17-hydroxycorticosteroid (17-OHCS) was as low as $0.03 \mathrm{mg} /$ day. Treatment with hydrocortisone and $9 \alpha$-fluorocortisone acetate recovered and maintained the serum sodium and potassium at normal levels. Breast budding and menarche were observed at the ages of 12 and 13 respectively. Her menstrual cycle had shown a 25-day cycle with an occasionally irregular rhythm. At the age of 25 , breast development was at the Tanner stages 3-4, and the pubic hair distribution was at Tanner stage 2. The axillary hair looked lanugo. Right ovarian cysts were detected by ultrasonography at age 23 and the size of the whole ovary was $54 \times 35 \mathrm{~mm}$. One month later, computed tomography revealed various sizes of ovarian cysts in both ovaries, including cysts more than $20 \mathrm{~mm}$ in diameter. By DNA analysis of the StAR gene, a homozygous mutation of Q258X was found in the patient.

\section{Case 3}

A 1-month-old female Japanese patient was suspected of having CLAH due to hyponatremia, hyperkalemia and pigmentation. Biosynthesis of steroid hormone was decreased, showing that urinary 17-OHCS was decreased to $0.07 \mathrm{mg} /$ day. She was successfully treated with hydrocortisone and $9 \alpha$-fluorocortisone acetate. Breast budding and menarche were observed at the ages of 14 and 15 respectively. At the age of 17 , basal luteinizing hormone (LH) level was as high as $11.2 \mathrm{mIU} / \mathrm{ml}$ and had an exaggerated response to LHreleasing hormone (LH-RH): the LH levels 30, 60, 90 and $120 \mathrm{~min}$ after giving LH-RH were 49.3, 42.3, 63.3 and $35.5 \mathrm{mIU} / \mathrm{ml}$ respectively. However, the folliclestimulating hormone (FSH) response to $\mathrm{LH}-\mathrm{RH}$ was normal. The development of breasts and pubic hair at age 24 was at the Tanner stages of 5 and 2-3 respectively. Ovarian cysts were not detected by ultrasonography. In the analysis of the StAR gene, the compound heterozygotic mutation with 251 insG and Q258X was detected.

\section{Materials and methods}

The following examinations were performed at the age of 13 in case 1,24 in case 2 and 25 in case 3 . In a normal control in whom menarche was observed at the age of 13 years 8 months, urinary gonadotropin, estradiol and pregnanediol levels were measured at the age of 16. Serum levels of LH and FSH were determined by immunoradiometric assay. LH-RH test was performed as described previously (8). First-morningvoided urine specimens were obtained from the patients and control and stored at $-20{ }^{\circ} \mathrm{C}$ until determination. 
Table 1 Characteristics of the three CLAH patients.

\begin{tabular}{lccccccccc}
\hline Case & Age & $\begin{array}{c}\text { StAR gene } \\
\text { abnormality }\end{array}$ & $\begin{array}{c}\text { Breast budding, } \\
\text { menarche (years) }\end{array}$ & $\begin{array}{c}\text { Basal LH } \\
(\mathrm{mlU} / \mathrm{ml})\end{array}$ & $\begin{array}{c}\text { Basal FSH } \\
(\mathrm{mlU} / \mathrm{ml})\end{array}$ & $\begin{array}{c}\text { Estradiol } \\
(\mathrm{pg} / \mathrm{ml})\end{array}$ & $\begin{array}{c}\text { Progesterone } \\
(\mathrm{ng} / \mathrm{ml})\end{array}$ & $\begin{array}{c}\text { Testosterone } \\
(\mathrm{ng} / \mathrm{ml})\end{array}$ & $\begin{array}{c}\text { Ovarian } \\
\text { cysts }\end{array}$ \\
\hline 1 & 13 & 840delA/Q258X & 9,10 & 11.2 & 4.9 & 25 & $<0.2-1.2$ & $<0.1$ & + \\
2 & 24 & Q258X/Q258X & 12,13 & 12.7 & 4.1 & 91 & $<0.2-0.3$ & $<0.1$ & + \\
3 & 25 & 251 insG/Q258X & 14,15 & 14.6 & 4.4 & 42 & $<0.2$ & $<0.1$ & - \\
\hline
\end{tabular}

The specimens were centrifuged at 3000 r.p.m. for $5 \mathrm{~min}$ and then urinary gonadotropin levels were determined by immunofluorometric assay as described previously (9). The assay sensitivities were $0.2 \mathrm{mIU} / \mathrm{ml}$ for both LH and FSH. Estradiol and pregnanediol levels in urine were measured by radioimmunoassay and gas chromatography after hydrolysis of the samples (SRL Co., Tokyo, Japan), and the detection limits were 0.2 $\mathrm{ng} / \mathrm{ml}$ and $0.02 \mathrm{mg} / \mathrm{l}$ respectively. The intra-assay and interassay coefficients of variation for urinary estradiol and pregnanediol did not exceed $7.9 \%$ and $5.8 \%$ respectively. Serum estradiol, progesterone and testosterone were determined by radioimmunoassay and the detection limits were $10 \mathrm{pg} / \mathrm{ml}, 0.2 \mathrm{ng} / \mathrm{ml}$ and $0.1 \mathrm{ng} / \mathrm{ml}$ respectively (Nippon DPC Co., Chiba, Japan) (10). Urinary creatinine $(\mathrm{Cr})$ was determined by a colorimetric method (Creatinine test, Wako Co., Osaka, Japan). Urinary gonadotropin and ovarian hormones were related to the creatinine concentrations. StAR gene analysis was carried out as reported previously (11).

Written informed consent for this study was obtained from all patients or their parents.

\section{Results}

The basal body temperature was not biphasic in any patient. The basal LH levels (normal range, 0.4$4.1 \mathrm{mIU} / \mathrm{ml}$ ) were elevated in the three CLAH patients (Table 1). In case 1 , the basal LH level measured early in the menstrual cycle was increased at $11.2 \mathrm{mIU} / \mathrm{ml}$ and had an exaggerated response to LH-RH; the peak level of LH $30 \mathrm{~min}$ after giving LH-RH was $51.8 \mathrm{mIU} / \mathrm{ml}$ (Fig. 1 ). The basal LH levels determined at 6-month intervals ranged from 7.3 to $14.5 \mathrm{mIU} / \mathrm{ml}$ after age 11 , showing that the LH secretion was enhanced when the ovarian cysts were found in the patient. The basal LH levels in cases 2 and 3 were also elevated at the ages of 24 and 25 respectively (Table 1 ). The basal FSH levels (normal range, $4.8-10.4 \mathrm{mIU} / \mathrm{ml}$ ) were within the normal range in all patients (Table 1), and the FSH response to $\mathrm{LH}-\mathrm{RH}$ was normal in case 1 . The circulating levels of estradiol ranged from 25 to $91 \mathrm{pg} / \mathrm{ml}$ and those of progesterone were $<0.2$ to $1.2 \mathrm{ng} / \mathrm{ml}$.

Analysis of first-morning urine samples in the normal control before menarche revealed random fluctuations in urinary LH and FSH, in which FSH levels were increased compared with LH in each fluctuation (Fig. 2). Urinary estradiol also showed low-amplitude fluctuations while pregnanediol excretion remained almost undetectable. The analysis in the same normal control after menarche showed a gonadotropin surge, estradiol peak and subsequent increase of pregnanediol (Fig. 2). Thus, examination of gonadotropin and ovarian hormones in morning urine samples expressed per gram of creatinine $(\mathrm{Cr})$ was useful to evaluate circulating hormones, as reported previously (12). The control peak levels of urinary LH, FSH, estradiol and pregnanediol were $5.4 \mathrm{IU} / \mathrm{gCr}, 8.2 \mathrm{IU} / \mathrm{gCr}, 2.6 \mu \mathrm{g} / \mathrm{gCr}$ and $0.1 \mathrm{mg} / \mathrm{gCr}$ in pre-menarcheal, and $18.0 \mathrm{IU} / \mathrm{gCr}, 3.7 \mathrm{IU} / \mathrm{gCr}, 18.7 \mu \mathrm{g} /$ $\mathrm{gCr}$ and $3.3 \mathrm{mg} / \mathrm{gCr}$, post-menarcheal (Fig. 2). In case 1, urinary estradiol early in the menstrual cycle was

나

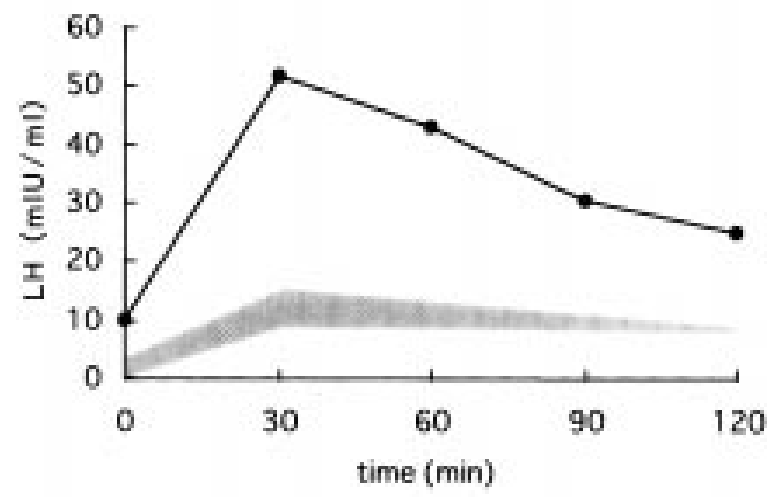

FSH

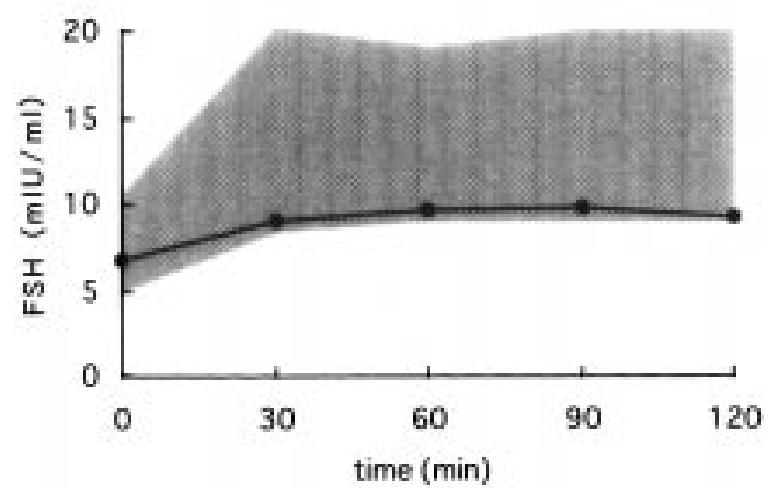

Figure 1 Levels of LH and FSH in response to $100 \mu \mathrm{g} \mathrm{LH}-\mathrm{RH}$ in case 1. Shaded area: normal range. 

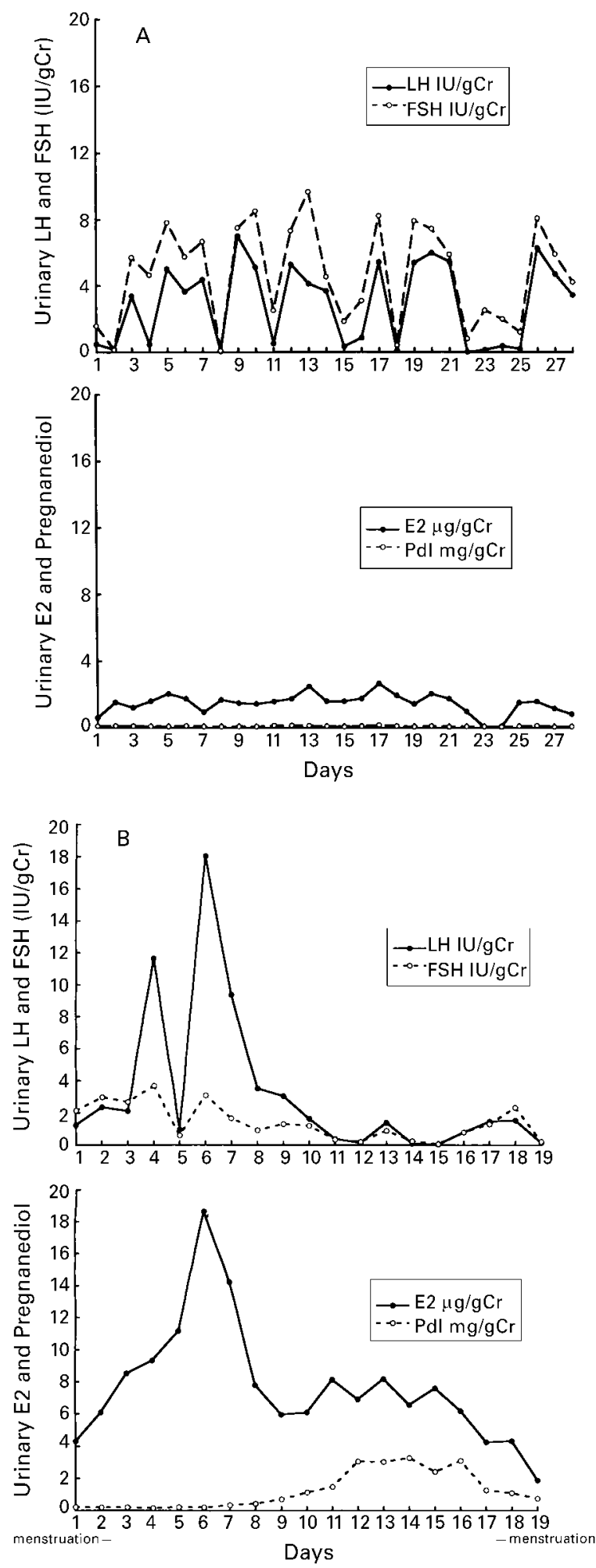

Figure 2 Urinary LH, FSH, estradiol $\left(\mathrm{E}_{2}\right)$ and pregnanediol (pdl) levels in normal control, in whom menarche was observed at the age of 13 years 8 months. (A) Pre-menarcheal, at the age of 13 years 5 months; (B) the same normal control after menarche, age 16 years 7 months. Gonadotropin surge and estradiol peak were observed at the same time.
$2.1 \mu \mathrm{g} / \mathrm{gCr}$ and was slightly increased mid-way through and late in the cycle (Fig. 3), but no apparent peak was observed. In cases 2 and 3, urinary gonadotropin analysis revealed many surges of LH and FSH (Fig. 3). The urinary estradiol levels ranged from 2.2 to $29.6 \mu \mathrm{g} /$ $\mathrm{gCr}$ in case 2 and from 4.1 to $13.8 \mu \mathrm{g} / \mathrm{gCr}$ in case 3 , and the levels were comparable to the normal control (Fig. 2). However, in contrast to the normal control, the gonadotropin surges in cases 2 and 3 were not accompanied by a peak of urinary estradiol (Fig. 3). The levels of urinary pregnanediol were low even late in the cycle in case 1 and were undetectable in cases 2 and 3 , suggesting that ovulation was not observed in any of the CLAH patients (13) (Fig. 3). The serum testosterone levels were undetectable in all subjects.

\section{Discussion}

Despite the abnormality of the StAR gene, breast budding and menarche occurred, as shown in Table 1, as reported previously (5). The serum concentration of estradiol, which plays an important role in development during puberty, ranged from 25 to $91 \mathrm{pg} / \mathrm{ml}$. The reason why only serum estradiol was detectable remains unclear. We speculated that pregnenolone, which maintains the level of estradiol, was produced, although in a limited quantity, in the ovary by an unknown mechanism despite the mutation in the StAR gene. Estradiol is detectable at levels as low as $10 \mathrm{pg} / \mathrm{ml}$ and has biological activity around this level (14), while other steroid hormones such as cortisol and dehydroepiandrosterone sulfate need much higher concentrations to exhibit biological activity and to be detected. Thus, estradiol was the steroid hormone found most often in the serum, probably due to the sensitivity of the assay.

To induce the surge of $\mathrm{LH}$ and FSH by a positive feedback mechanism, a great increase in serum estradiol over the basal level is crucial. In case 1 , no peak in the urinary estradiol level was detected throughout the menstrual cycle, probably because of the limited supply of pregnenolone in the ovary. Although the serum estradiol level was $25 \mathrm{pg} / \mathrm{ml}$, there was no additive secretion of estradiol. Thus, the patient was estrogen-deficient and the absence of the estradiol peak may have resulted in the anovulation. In cases 2 and 3, frequent LH and FSH surges were observed throughout the menstrual cycle, probably due to increased sensitivity of the anterior pituitary to releasing hormone stimulation by circulating estrogen (13). The exaggerated LH response to LH-RH in case 1 can be explained by the same mechanism. Repetitive gonadotropin surges were observed in cases 2 and 3 but were not frequent in case 1. One possible explanation is the difference in age between case 1 and cases 2 and 3 . Another explanation is that the increases in amplitude and frequency of LH secretion are correlated with the circulating estradiol level (13). Since the estradiol level 

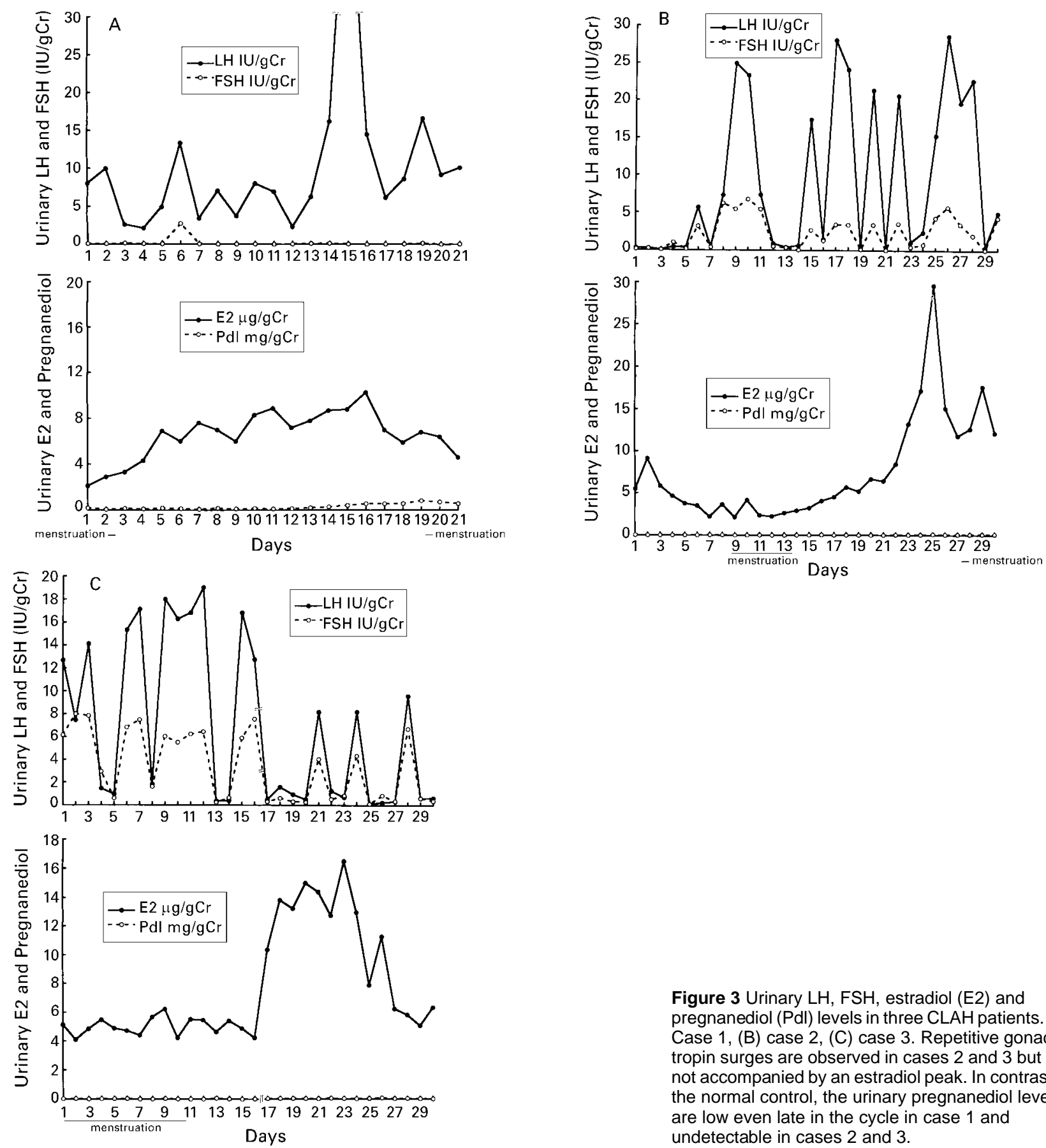

was low in case 1 compared with cases 2 and 3, the frequency and amplitude in gonadotropin surges may be decreased. Although LH and FSH surges were observed throughout the menstrual cycle in cases 2 and 3, ovulation did not take place, which is supported by the non-biphasic basal body temperature and undetectable urinary pregnanediol. The precise mechanism remains unknown, but we speculate that the gonadotropin surge did not induce ovulation

without antecedent follicular maturation and the estradiol peak.

In the mother of a patient with male-limited precocious puberty, which is transmitted in an autosomal dominant manner and is caused by an activating mutation of the LH receptor, no ovarian abnormalities were reported (15). These observations suggest that LH stimulation is not associated with the development of ovarian cysts. Thus, a possible explanation for the 
ovarian cysts is prolonged anovulation and impaired formation of the corpus luteum in CLAH patients. This speculation is based on a study of a patient with $\mathrm{LH}$ receptor defect who developed amenorrhea and ovarian cysts. The non-luteinized degenerating follicles formed as a result of anovulation (16). Continued anovulation was also observed in CLAH patients and may involve the formation of ovarian cysts. Androgen is involved in polycystic ovary syndrome in patients with congenital adrenal hyperplasia $(17,18)$. However, in our cases, androgen was not a likely factor, because serum levels of androgen were undetectable.

In summary, basal estradiol influences development during puberty and induces the repetitive surges of $\mathrm{LH}$ and FSH throughout the menstrual cycle. However, ovulation does not take place. Development of ovarian cysts may be derived from persistent anovulation. Thus, the presence of ovarian cysts should be considered and long-term follow-up is necessary in patients with CLAH.

\section{Acknowledgements}

We would like to express our thanks to Drs Keiichi Ozono and Masahiro Sakata for their valuable suggestions. This work was supported in part by a Grant-in-Aid from the Ministry of Education, Science and Culture, Japan, and Grants for Pediatric Research (10C-2, 10C-3) from the Ministry of Health and Welfare, Japan.

\section{References}

1 Prader A \& Siebenmann RE. Nebennieren Insuffizienz bei kongenitaler Lipoid-hyperplasie der Nebenniern. Helvetica Paediatrica Acta 195712 569-595.

2 Lin D, Gitelman SE, Saenger P \& Miller WL. Normal genes for the cholesterol side chain cleavage enzyme, P450scc, in congenital lipoid adrenal hyperplasia. Journal of Clinical Investigation 199188 1955-1962.

3 Clark BJ \& Stocco DM. Expression of the steroidogenic acute regulatory (StAR) protein: a novel LH-induced mitochondrial protein required for the acute regulation of steroidogenesis in mouse leydig tumor cells. Endocrine Research 199521 243-257.

4 Lin D, Sugawara T, Strauss JF, III, Clark BJ, Stocco DM, Saenger P et al. Role of steroidogenic acute regulatory protein in adrenal and gonadal steroidogenesis. Science 1995267 1828-1831.

5 Bose HS, Pescovitz OH \& Miller WL. Spontaneous feminization in a 46,XX female patient with congenital lipoid adrenal hyperplasia due to a homozygous frameshift mutation in the steroidogenic acute regulatory protein. Journal of Clinical Endocrinology and Metabolism 199782 1511-1515.

6 Bose HS, Sugawara T, Strauss JF, III \& Miller WL. The pathophysiology and genetics of congenital lipoid adrenal hyperplasia. New England Journal of Medicine 1996335 1870-1878.

7 Fujieda K, Tajima T, Nakae J, Sageshima S, Tachibana K, Suwa S et al. Spontaneous puberty in $46, \mathrm{XX}$ subjects with congenital lipoid adrenal hyperplasia: ovarian steroidogenesis is spared to some extent despite inactivating mutations in the steroidogenic acute regulatory protein (StAR) gene. Journal of Clinical Investigation $1997991265-1271$.

8 Shima M, Nose O, Shimizu K, Seino Y, Yabuuchi H \& Saito T. Multiple associated endocrine abnormalities in a patient with pseudohypoparathyroidism type 1a. European Journal of Pediatrics $1988147536-538$.

9 Ito J, Tanaka T, Tanae A \& Hibi I. Measurement of urinary gonadotropins using immuno-fluorometric assay. Clinical Pediatric Endocrinology 19954 7-15.

10 Mio Y, Onohara Y, Sekijima A, Harada T, Iwabe T \& Terakawa N. Subtle rise in serum progesterone during the follicular phase as a predictor of the outcome of in vitro fertilization. Fertility and Sterility 199258 159-166.

11 Katsumata N, Tanae A, Shinagawa T, Nagashima-Miyokawa A, Shimizu M, Yasunaga T et al. Detection of the missense mutation A218V in the steroidogenic acute regulatory protein gene of a Japanese patient with congenital lipoid adrenal hyperplasia. Clinical Pediatric Endocrinology 19976 33-37.

12 Maesaka H, Tachibana K, Adachi M \& Okada T. Monthly urinary gonadotropin and ovarian hormone excretory patterns in normal girls and female patients with idiopathic precocious puberty. Pediatric Research 199640 853-860.

13 Speroff L, Glass RH \& Nasa NG. Clinical Gynecologic Endocrinology and Infertility, pp 220-231. Baltimore: Williams \& Wilkins, 1989.

14 Winter JSD, Faiman C \& Reyes FI. Normal and abnormal pubertal development. Clinical Obstetrics and Gynecology 1978 21 67-86.

15 Shenker A, Laue L, Kosugi S, Merendino JJ, Jr, Minegishi T \& Cutler GB, Jr. A constitutively activating mutation of the luteinizing hormone receptor in familial male precocious puberty. Nature 1993365 652-654.

16 Latronico AC, Anasti J, Arnhold IJP, Rapaport R, Mendonca BB, Bloise $\mathrm{W}$ et al. Testicular and ovarian resistance to luteinizing hormone caused by inactivating mutations of the luteinizing hormone-receptor gene. New England Journal of Medicine 1996 334 507-512.

17 Sizonenko PC, Schindler AM, Kohlberg IJ \& Paunier L. Gonadotrophins, testosterone and oestrogen levels in relation to ovarian morphology in $11 \beta$-hydroxylase deficiency. Acta Endocrinologica 197271 539-550.

18 Axelrod LR, Goldzieher JW \& Ross SD. Concurrent 3 $\beta$-hydroxysteroid dehydrogenase deficiency in adrenal and sclerocystic ovary. Acta Endocrinologica 196548 392-412.

Received 20 May 1999

Accepted 3 November 1999 